\title{
Ten Years of Micro-CT in Dentistry and Maxillofacial Surgery: A Literature Overview
}

\author{
Ilaria Campioni ${ }^{1, *(\mathbb{D}}$, Raffaella Pecci ${ }^{2, *}$ (i) and Rossella Bedini ${ }^{2}$ (I) \\ 1 Independent Researcher, 00161 Rome, Italy \\ 2 National Centre of Innovative Technologies in Public Health, Istituto Superiore di Sanita, 00161 Rome, Italy; \\ rossella.bedini@iss.it \\ * Correspondence: ilaria.campioni@gmail.com (I.C.); raffaella.pecci@iss.it (R.P.)
}

Received: 18 May 2020; Accepted: 22 June 2020; Published: 24 June 2020

\begin{abstract}
Micro-computed tomography (micro-CT) is a consolidated imaging technology allowing non-destructive three-dimensional (3D) qualitative and quantitative analysis by the observation of microstructures with high resolution. This paper aims at delivering a structured overview of literature about studies performed using micro-CT in dentistry and maxillofacial surgery (MFS) by analyzing the entire set of articles to portray the state of the art of the last ten years of scientific publications on the topic. It draws the scenario focusing on biomaterials, in vitro and in/ex vivo applications, bone structure analysis, and tissue engineering. It confirms the relevance of the micro-CT analysis for traditional research applications and mainly in dentistry with respect to MFS. Possible developments are discussed in relation to the use of the micro-CT combined with other, traditional, and not, techniques and technologies, as the elaboration of 3D models based on micro-CT images and emerging numerical methods. Micro-CT results contribute effectively with whose ones obtained from other techniques in an integrated multimethod approach and for multidisciplinary studies, opening new possibilities and potential opportunities for the next decades of developments.
\end{abstract}

Keywords: micro-computed tomography; dentistry; maxillofacial surgery; literature overview

\section{Introduction}

The first X-ray microtomography or micro-computed tomography (micro-CT) system was conceived in the early 1980's, and in 1994, the first commercially available bone micro-CT scanner was presented [1,2].

Nowadays, micro-CT systems are present as lab instrumentations at main laboratories and companies to perform different types of investigations and for various applications, including educational purposes [3,4]. Micro-CT represents one of the main methods to perform non-destructive analysis and one of the most common microscopy methods [5] where the very fine scale internal structure of objects is imaged, providing high resolution volumetric data at a micron level. It allows for the investigation of microstructures, the accuracy detection of the geometries [6-9], eventually defects and difference in density and morphology. It does not require specimen preparation, staining and slicing; settings and parameters were extensively studied for specific structures [10].

It has great potential for biomedical and bioengineering applications [11]. The analyses carried out by micro-CT can be helpful also in terms of compliance to international standards, regulations, and in forensic practice [12,13]. Microtomographic analyses can affect the validation process of materials and the quality assessment of final devices. Recently, in the medical device sector, the growing interest in emerging manufacturing techniques as the additive ones, allowed to recognize micro-CT as one of the major tools for the product quality assessment and for the quality control of additive manufacturing (AM) products and materials [6,14-16]. 
Dentistry and maxillofacial surgery (MFS) represent two sectors that affect the biomedical engineering context and in which there was an extensive use of the micro-CT due to the necessity to acquire detailed information of small and complex objects, mineralized structures [17-19], and with different densities. The market is characterized by innovative materials and solutions that require advanced technology in routine-based activity of dental labs and clinics as the micro-CT scanning [20], whose capabilities turn out to be indispensable [21-23].

The authors have extensive knowledge and experience about micro-CT and its application in biomedical studies and in both fields addressed here [6,7,24-31]. Specifically, in this work, the first author (I. Campioni) independently reviewed and organized the records identified from the database searches to assess the initial eligibility and both the authors (I. Campioni and R. Pecci) fully reviewed the search results. Disagreements were resolved by reaching a consensus or consulting the third and senior author (R. Bedini). In the early 2000's, R. Bedini believed in such technology and had engaged many research funds in the purchase of equipment to perform three-dimensional (3D) microtomography and to undertake research collaborations to study the effectiveness of this 3D methodology compared to the traditional ones, such as histology and electron microscopy [7,8,15,24-28,30-32].

The aim of the present paper is to deliver a structured overview of the literature, highlighting the main applications of micro-CT in dentistry and MFS, and considering the set of articles published in English from 2010 to January 2020 in PubMed/MEDLINE and Scopus (excluding Medline records from search results). A primary search was based on the following set of keywords: (i) ("micro-computed tomograph" OR micro-CT) AND (dentistry OR "maxillofacial surgery") for-Title, Abstracts, and Keywords. A secondary search was performed in MEDLINE on this set of keywords: (ii) (micro-computed tomography OR micro-CT) AND (dentistry OR maxillofacial) for All Fields and applying a filter limiting to the type of study "Review". Furthermore, the work has the goal to address the studies involving lab-based applications of micro-CT for research and clinical purposes, thus it does not include the synchrotron-radiation-based X-ray micro-CT [2,33-38] and related applications of the latter with other technologies [39]. Considering time and resources, grey literature, as well as conference proceedings and abstracts related to the topic (e.g., [40-44]) were not investigated.

Therefore, the literature overview aims to answer to the following main questions:

- Which have been the main dentistry and MFS applications of micro-CT during the last 10 years?

- What are the main literature reviews in 10 years?

- What will be the possible future scenario for the micro-CT development?

The graphical representation of Figure 1 summarizes the main aspects assessed, organized for topics, including future orientations, and discussed in the following sections.
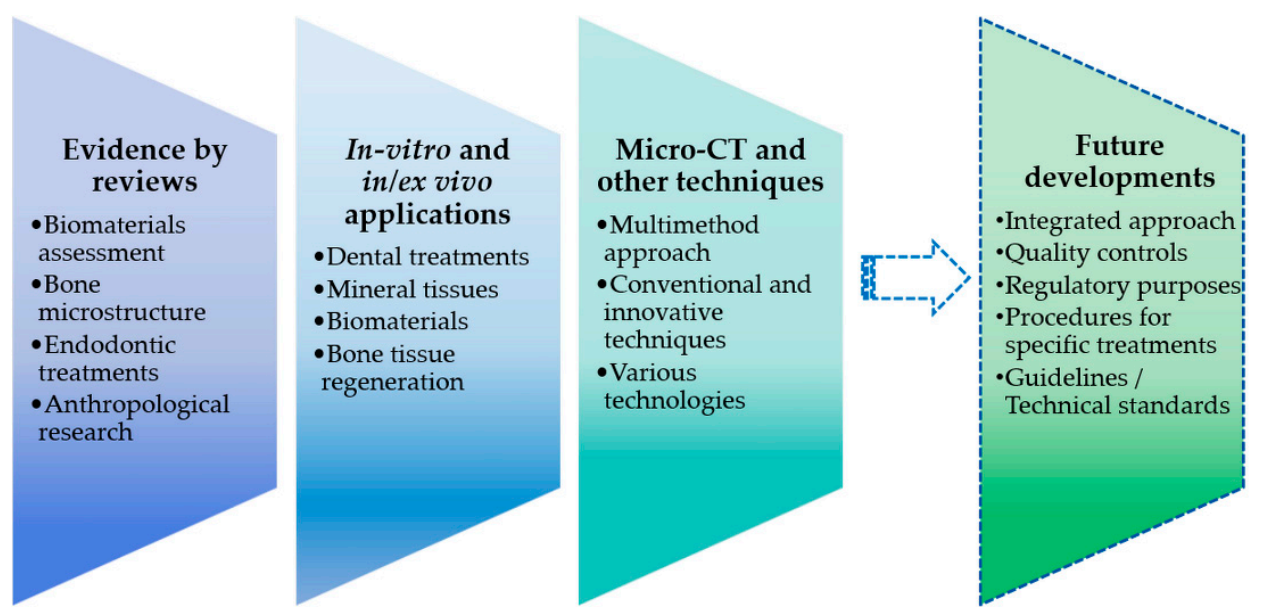

Figure 1. Main aspects discussed in the following paragraphs and organized for topics. 


\section{Evidence and Effectiveness by Literature Reviews}

In the last ten years, some literature reviews were published with the aim to assess, directly and indirectly, micro-CT traditional and not applications. Regarding dentistry and MFS fields, the main topics investigated were related to biomaterials, bone evaluation, specific aspects in dentistry, as the root canal preparation, the correlation with other techniques and, not excluding the less common applications of the technology as anthropological research.

In dentistry, it resulted that micro-CT allows biomaterials assessment, a precise analysis of materials used and the main parameters, as surface area, surface structure, internal structure, porosity, and the nature of the connection among them and the living tissue [21]. It represents a highly accurate method for the assessment of the polymerization shrinkage in composite restorations [45]. Furthermore, it is also cited in a systematic review, as a measurement method for ceramic crowns evaluation, providing sections of the marginal area and recognition of the critical distances [46].

Root canal filling materials, as endodontic treatments, have, as their objective, the appropriate sealing of the space caused by the root canal [47]. The analysis of the literature systematic reviews and overviews recorded by the database search evidenced an amount of studies focused on the application of micro-CT for the evaluation of the root canal and periapical lesions [48]. The morphology [49], the porosity of the endodontic materials [47], the assessment of different techniques of cavity preparation $[21,50]$ or of a specific shaper [51], the shaping effects of instruments and instrumentation comparing the root canal morphology before and after the preparation [52] and the effectiveness of different instrumentation procedures in removing feeling materials [53], are the main aspects investigated.

It is considered as a methodology for the determination of mineral density [54,55], complex structures of the bone, trabecular bone microstructure [56], not excluding teeth and in general mineralized tissues.

The assessment of the density of minerals in enamel and dentin, the detection of demineralization in caries, the measurement of the depth of cavities in dentin, the evaluation of microleakage around fillings and fissure sealants [21], are some of the main applications. Compared with cone beam computed tomography (CBCT) images, micro-CT is likely to have better diagnostic accuracy for carious lesions, tooth resorption, periodontal disease, and intra-operative imaging [57].

The traditional use of micro-CT for the bone evaluation in dentistry and bone tissue regeneration applications is the main topic discussed by literature reviews [32]. The possibility to obtain information about bone tissue microarchitecture and composition is in relation to the importance to perform accurate analysis starting from the sample preparation, the quantitative assessment to the final 3D reconstruction, with special attention to the settings of the appropriate parameters during the acquisition step [58]. The design and the characterization of scaffolds benefit from the advantages offered by microtomographic analysis for the morphometric structural investigation [59]. The evaluation of bone remodeling is a main topic not only in dentistry but also in the MFS sector. Reviews on new regenerative strategies [60] and rodent jawbone micro-architecture [61] evaluated by micro-CT, were performed, underlining the need for a standardized methodology [61].

Lastly, other applications discussed in MFS and dentistry reviews are related to anthropological and evolutionary research improving the assessing of dental tissues and elucidating the roles of genetic, epigenetic, and environmental factors on phenotypic variations in craniofacial features [57].

\section{Micro-CT Studies: In Vitro and In/Ex Vivo Applications}

The cost of in vivo animal studies and the loss of animal lives continue to motivate the development of in vitro screening assays [59]. Despite this, in vivo protocols in bone tissue engineering remain a common investigation to study specific issues and which use micro-CT as the main tool for the analysis. Both types of studies, in vivo and in vitro, are also carried out together considering various analyses and techniques [62]. Moreover, ex vivo studies are reported for the assessment of bone and specific treatments. 


\subsection{Dental Treatments and Mineral Tissues}

Restorative treatments in dentistry to ensure the integrity of the teeth and of their supporting tissues benefit of micro-CT imaging.

In particular, benefits are reported for: the analysis of molars morphology and tooth structure [63]; the positional relationship of the crown contour and the pulp chamber of first molars [64]; and the efficacy of polishing and glass infiltration on the wear behavior of monolithic zirconia crowns [65].

Dental caries is characterized by demineralization and the degeneration of organic matrix [66]. Micro-CT analysis resulted helpful to evaluate the validation of temporary and innovative restoration solutions [67]. The mineralization of carious enamel for the identification of a regenerative treatment solution for dental caries [68], as well as the demineralization of tissues, as the enamel adjacent to restoration margins in cavities filled with experimental composites, from extracted bovine incisors [69], are some of the aspects that were investigated.

Furthermore, there were assessed:

- the marginal integrity and quality of composite fillings [70].

- the effects, in adhesive dentistry, of different drying methods for post space dentin bonding in a direct resin composite core build-up method [71].

- the effectiveness of two resins [72].

The analysis of the accuracy of enamel and dentin thickness [73] as well as of teeth dimensions [74] benefits of micro-CT 3D measurements. It was applied to observe human molars characteristics before performing the micro tensile test [75]. A case study reports that the analysis of extracted teeth in children allowed the early correct diagnosis [76]. The capability of micro-CT to acquire morphometric information of structures resulted in being relevant for the detection of significant differences in mandibular volumes and dental morphology in relation to a specific syndrome [77]. Moreover, clinical consequences of genetic disorders that affect ossification, and consequently dental anomalies, resulted in being diagnosable by microtomographic assessment $[78,79]$.

One of the main limitations of current dental practice is to preserve in time the effect of treatments. The treatment of root canal characterized by the loss of apical root material is a clinical issue, extensively investigated in the literature. The effects of treatments are commonly assessed by micro-CT to quantitatively evaluate the root surface resorption after the extraction of the teeth. It was used in a study aimed to design and realize a method for analyzing the geometrical characteristics of human root canals, calculated by a self-implemented image evaluation algorithm [80]. It was applied to evaluate morphology [81-83], microcrack formations [84,85], root fractures [86], the presence of voids in oval root canals filled with different root canal sealers [87]. It was considered to assess the efficacy of methods for removing root filling materials or for cleaning the canal $[88,89]$, the influence of endodontic cavities on the preservation of the original root canal anatomy after shaping with nickel-titanium rotary instruments [90], and the correlation between geometric parameters of root filled teeth and the fracture resistance [91]. Multiple scansions were elaborated preoperatively, after preparation and obturation of the canal with gutta-percha, on extracted mandibular first molar teeth, to compare the quality of obturation in the apical third of the root [92]. Furthermore, photobiomodulation applications on root resorption are reported, considering a study on 30 patients [93].

The various applications of the current dental practice including the use of the micro-CT, let emerge the importance to define procedures for performing microtomographic analysis at least for specific treatments. The various methodologies applied as well as the reconstruction techniques also based on self-made algorithms and the timing to carry out the analyses, created a scenario in which it was difficult sometimes for scientists and, particularly for clinicians, to have clinical evidence comparable and referable. Specific procedures, in terms of guidelines and technical standards, could improve the efficacy and effectiveness in the application of the micro-CT and could allow clinicians in performing a more efficient analysis for a useful and routine implementation. 
Finally, micro-CT had a relevant role in multidisciplinary approaches. It contributed to reveal the method used for the realization of the dental prosthesis, a golden dental appliance [94], and to characterize osseous lesions in the analysis of burials discovered during archeological excavations [95].

\subsection{Biomaterials and Bone Tissue Regeneration}

3D micro-CT scans were usually conducted to evaluate bone reformation, bone mineral density, remodeling, the scaffold morphology, and the biomaterial structure performing in vitro and in/ex vivo studies.

The use of animal models seems to be a required step in testing new bone regeneration materials [96]. The in vivo applicability of bioengineered 3D constructs [97] and bone graft substitutes is usually evaluated in animals models as rats, rabbits, mini pigs bone defects, and applications are recorded in dentistry [98-102] as in MFS [103-105]. Mainly, the biomaterials and bone grafts investigated for tissue engineering applications are:

- Uncalcined and unsintered hydroxyapatite/poly-D/L-lactide with beta-tricalcium phosphate (b-TCP) [104] or with human mesenchymal stem cell [103].

- Granular deproteinized bovine bone and b-TCP alone or with dental pulp stem cells [62].

- Polycaprolactone-tricalcium phosphate (PCL-TCP) [102].

- Nano-hydroxyapatite/collagen composite [106].

- Nanofibrous bone graft coupled with osteoinductive proteins/peptides-poly(D,L-lactide-co -glycolide)/collagen/gelatin [99].

- Bioresorbable collagen membranes [96,107].

- Silk fibroin scaffolds [108].

- Injectable scaffold based on oxidized alginate microbeads encapsulating periodontal ligament stem cells and gingival mesenchymal stem cells [109].

The in vitro applicability of bone graft substitutes is usually evaluated on extracted teeth in dentistry as in the studies conducted on polylactic acid (PLA)-based mineral-doped scaffolds [110] and in MFS [105]. Turco et al. performed a comparison of the biological, chemical, and structural features of four different commercially available bone substitutes derived from an animal or a synthetic source, analyzing the biomaterials structures by micro-CT [111].

A common problem in clinical dentistry is the significant and rapid bone loss that occurs after tooth extraction, traumatic events, and surgery. The possibility to have a fast repair of bone defects is a challenge [112] and research has been conducted to investigate the various treatments. Micro-CT quantification of histomorphometric data was applied in animal studies to evaluate the effect of injected protein on alveolar bone [113], high-frequency acceleration, and the rate of bone formation after tooth extraction [114].

The osseointegration is another main aspect investigated performing a microtomographic analysis. Structural parameters of bone as, volume, trabecular thickness, trabecular number, trabecular separation, and total porosity, are the more significant parameters usually assessed and evaluable by micro-CT for the bone characterization, under various conditions, in studies conducted on patients [115]. In vitro experiments were carried out on coatings and correlated to micro-CT information about bone morphology to examine osseointegration [116]. Micro-CT allowed to demonstrate that a bisphosphonate treatment for osteoporosis, can invert the negative effect of osteoporosis on osseointegration, promote osseointegration itself and, the fixation of dental implants in autologous bone grafts under osteoporotic condition [117]. Furthermore, bone tissue response and osseointegration were investigated in experimental animal protocols, in relation to a bioactive silicate coating [118], lightweight implants [119],

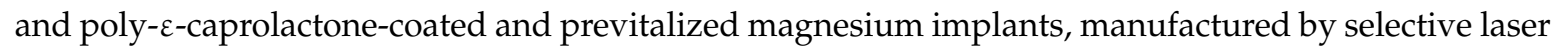
melting technology [120], alternative to traditional implants in MFS and new implants with modified surfaces, in comparison with commercially available dental implants [121]. Titanium implants were 
microtomographic observed and induced osteolysis was addressed [122], as well as newly formed bone in bioactive coated implants [118].

Finally, about bone tissue applications in MFS, micro-CT measurements of trabecular porosity allowed to provide quantitative evidence that laser-mediated cutting preserves the trabecular architecture and reduces thermal and mechanical damage at the margins of the cut [123].

\section{Micro-CT Analysis Combined with Other Techniques or Technologies}

In the last years, the microtomographic investigation has been often combined with other techniques and technologies, for example, it is applied as a preliminary step before destructive testing, to obtain data and models to be used for volumetric measurements in reverse engineering [65], computational and numerical applications. The analysis of the selected records allows detecting some studies, in which a multimethod approach was considered, incrementing the investigation power of micro-CT and its potential applications.

Figure 2 summarizes the techniques and technologies that emerged in studies about combined and integrated applications with micro-CT.

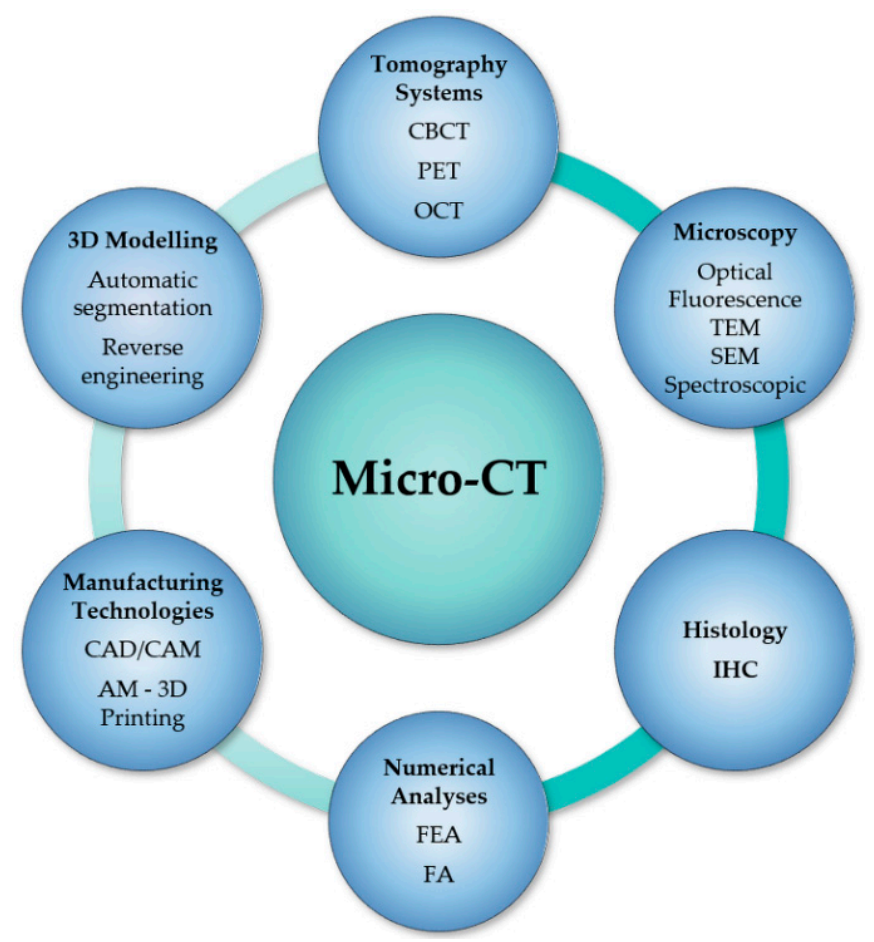

Figure 2. Main techniques and technologies applied with the micro-computed tomography (micro-CT) in the collected studies.

Firstly, it should be noted that micro-CT is not the only one tomography system applied in dentistry and MFS. As previously evidenced, some MFS devices and anatomical districts required to be acquired with systems allowing the scansion of objects with larger dimensions. Moreover, in clinical labs, some technologies are more common and routinely used.

The cone beam volume CT or CBCT is another kind of tomography system, X-ray based, commonly employed to assess the quality and quantity of bone. Despite that, micro-CT is combined with it due to the higher accuracy for small dimensions, for example, to obtain gold standard measurements of graft volumes in maxillary sinus augmentation procedure [124] or to determine how microarchitecture influences the morphology [125]. In recent years, the power of the available commercial systems is continuously growing in terms of range of dimensions and resolutions. 
Table 1 reports, as an example, the datasheets of the laboratory micro-CT and CBCT systems considered in the previous cited study [124] and of recent frequently used micro-CT models [67,93,99], also for larger object sizes [95], allowing the comparison of the technical specifications.

Table 1. Technical specifications of some commercial laboratory micro-CT and cone beam computed tomography (CBCT) systems.

\begin{tabular}{|c|c|c|c|c|}
\hline Specifications & Micro-CT Model: $\mu 40 *$ & $\begin{array}{l}\text { CBCT Model: } \\
\text { Accuitomo } 170 * *\end{array}$ & $\begin{array}{l}\text { Micro-CT Model: } \\
\text { SkyScan } 1172 * * *\end{array}$ & $\begin{array}{c}\text { Micro-CT Model: } \\
\text { Phoenix Nanotom } \mathbf{M}^{* * * *}\end{array}$ \\
\hline X-ray Source & $30-70 \mathrm{kV}$ & $60-90 \mathrm{kV}, 8 \mathrm{~mA}$ & $20-100 \mathrm{kV}, 10 \mathrm{~W}$ & $180 \mathrm{kV}, 20 \mathrm{~W}$ \\
\hline $\begin{array}{l}\text { X-ray Detector/Focal } \\
\text { Spot Size }\end{array}$ & $\begin{array}{l}2048 \times 256 \text { elements, } \\
24 \mu \mathrm{m} \text { pitch }\end{array}$ & Spot Size $0.5 \mathrm{~mm}$ & $\begin{array}{l}11 \mathrm{MP}, 12-\text { Bit Cooled } \\
\text { CCD Fiber-Optically } \\
\text { Coupled to Scintillator }\end{array}$ & $\begin{array}{c}\text { GE DXR, } 14 \text { Bit, } 3072 \times \\
2400 \text { Pixels }\end{array}$ \\
\hline $\begin{array}{c}\text { Max. Object } \\
\text { Size/Field of View }\end{array}$ & $\begin{array}{l}36.9 \times 80 \mathrm{~mm} \\
(\varnothing \times \mathrm{L})\end{array}$ & $\begin{array}{c}\text { Min. } \varnothing 40 \times 40 \\
\text { mmMax. Ø } 170 \times \\
120 \mathrm{~mm}\end{array}$ & $\begin{array}{l}\varnothing 27 \mathrm{~mm} \text { Single Scan } \\
\varnothing 50 \mathrm{~mm} \text { Offset Scan }\end{array}$ & $\begin{array}{c}240 \mathrm{~mm} \varnothing \times 250 \mathrm{~mm} \text { in } \\
\text { Height }\end{array}$ \\
\hline Detail Detectability & $3-72 \mu \mathrm{m}$ & $\begin{array}{c}80-250 \mu \mathrm{m} \text { voxel } \\
\text { size }\end{array}$ & $\begin{array}{l}0.5 \mu \mathrm{m} \text { at Highest } \\
\text { Magnification }\end{array}$ & Down to $0.2 \mu \mathrm{m}$ \\
\hline
\end{tabular}

“* (Scanco Medical AG, Zurich, Switzerland)”, “** (J Morita, Kyoto, Japan)”, “*** (Bruker microCT, Kontich, Belgium)”; “**** (GE Sensing \& Inspection technologies Gmbh, Wunstorf, Germany)”.

Another volumetric imaging technology is the positron emission tomography (PET). It is a different technology, even if it is a tomography as well, which uses small amounts of radiotracers or radiopharmaceuticals to evaluate organ and tissue functions. It was applied with micro-CT to investigate bone regeneration induced by scaffolds [62].

The importance to establish standard protocols for marginal and internal fit assessment of fixed prosthesis was investigated considering the association of micro-CT with various other imaging techniques. The optical coherence tomography (OCT), the triple scan and cross-sectional method are some of the techniques combined with microtomographic data to measure the marginal and internal fit by superimposing the 3D scan data of the prosthesis and the abutment tooth [126]. Modified commercially available spectral domain OCT measurements were also compared with micro-CT for assessing the abrasion of the orthodontic surface sealants [127].

Traditional methods applied in tissue engineering studies are based on techniques such as histology, scanning electron, and fluorescence microscopy imaging [32]. Microscopy technologies required to be mentioned, as they are usually associated with micro-CT in various applications.

Microstructural investigations made by both optical and scanning electron microscopy (SEM) are recorded in studies using transmission electron microscopy (TEM) to analyze adhesive/root dentin interface [71] and SEM for the quality assessment of composite fillings [70], porosity and size of silk scaffold [108], alginate samples with stem cells [109], and bone substitutes characterization in MFS [111]. SEM analysis with micro-CT was performed to characterize barrier membrane for bone augmentation in dentistry [128] and to study alloy composition of the metallic fixing lamina and microstructure of the deposits on the dental surface [94]. Comparison between backscattering SEM (bSEM) and microtomographic images, showed high correlations for bone volume per total volume (BV/TV) measurements in areas not affected by metal-induced artefacts [129].

Raman spectroscopic imaging, a laser-based microscopic device, was applied with micro-CT to examine bone samples and Charwat-Pessler et al. [98] reported that the two different imaging techniques provide complementary and mutually supportive information.

Finally, fluorescence lifetime imaging microscopy was used to image the complex morphologic features of dental sections without denaturing samples. Lin P. et al. [66] reported that the carious dental tissue exhibits a greatly reduced autofluorescence lifetime, which is consistent with the degree of demineralization, determined by micro-CT.

Histomorphological analysis were carried out for in vivo studies about the effects of bioactive coatings [118], bone graft substitutes [104,105], as well as confocal analysis, to examine the presence of live and dead cells after seeding on the experimental scaffolds at various days of culture [110]. Histology, as a traditional destructive analysis, was also reported combined with micro-CT for various 
applications, to assess: root fractures [86]; alveolar bone loss [114]; bone morphological changes [115]; new bone formation [96,102]; osseointegration in osteoporosis [117]; inflammatory response and vascularization using modified silk fibroin scaffolds [108]; bone tissue response of new zirconia implants with modified surfaces [121]; titanium [119]; and magnesium [120] implants for MFS and, maxillofacial trabecular bone microarchitecture and damage [123]. Moreover, immunohistochemical (IHC) analysis was performed with histology [109] and with immunofluorescent (IF), in studies related to tissue engineering applications [97].

One of the main potentials of micro-CT in recent years is associated to the emerging use of new manufacturing technologies for medical applications and, to the necessity of having high-resolution models as starting point for further analyses. Beyond that, the growing demand for personalized solutions in medicine implies for clinicians operating in dentistry and MFS, the possibility to elaborate specific devices and prototypes, and to directly experiment with new solutions.

Traditional manufacturing methodologies, as computer aided design (CAD), that had started to be used in association with computer-aided manufacturing (CAM), are nowadays more associated with new techniques as 3D printing and AM.

In this scenario, micro-CT analysis is defining a new role, also considering that conventional intra-oral scanner could be limited in terms of accuracy [9] for the acquisition of specific geometries and sizes. CAD/CAM, 3D printing, and AM benefit from microtomographic analysis to develop and validate solutions in dentistry, and MFS [120]. Rimawi et al. presented an integrated approach applying intra-oral scanner, $\mathrm{CBCT}$, micro-CT, 3D printing, and stereomicroscopy for temporary restoration of auto-transplanted teeth [67].

Micro-CT represents also a methodology for automatic segmentations $[130,131]$ and elaborations of accurate 3D models [132], even if some limitations in spatial resolutions and missing information have to be considered $[133,134]$. The possibility to create 3D micro-CT models based on reconstructed images has relevance in implementing numerical studies aimed to determine the more realistic operative conditions. CAD models can be easily elaborated, and after imported for post evaluations by other techniques. It allows obtaining information of the structure of the materials usable as input in computational studies, such as finite element analysis (FEA), simulating realistic different conditions.

FEA, a well-known computational numerical method was applied in dentistry and supported by microtomographic analysis to assess new models [135] or based on micro-CT reconstructed models and 3D images $[131,136]$. The main objectives detected of the numerical simulations implemented in literature are related to the evaluation of mechanical properties, the prediction of forces necessary to drill the cortical and trabecular bone [137], the biomechanical properties of the periodontal ligament [138], and the stress distribution in premolar under various occlusal loadings scenarios [139] or in root dentin [140].

Numerical analyses can be associated with the traditional destructive techniques for the mechanical characterization of structures and for the validation of the simulated data. Experimental mechanical testing techniques, performed respecting international standards or experimental protocols, continue to contribute and to corroborate with microtomographic, histomorphometric, and numerical data [91,116]. Finally, even if the information was collected in a record that is a review study not focused on micro-CT and, as it was not discussed previously [141], it is covered in this section for underlining the role of micro-CT in relation to the numerical method fractal analysis (FA). The FA is a mathematical method by which irregular, complex, and similar forms on various scales can be evaluated. The fractal dimension (FD) is the quantitative outcome [141]. In dentistry, the FA was employed in several studies. Kato et al., in their recent work about the use of FA in dental images, showed that FD was used on micro-CT images of porous titanium granules, bone graft materials, to assess the bone mineral density and, it was observed positive and negative correlations of FD values and other parameters such as histomorphometric analysis and radiographic bone density. Furthermore, they evidenced that few studies using this exam were carried out despite the high quality of micro-CT images and the importance of this aspect for a high-quality FA. The main causes are correlated to the high cost and the necessity of a 
bone sample that seems to preclude the use of micro-CT with FA. The power of the previously identified new role of the micro-CT in reference to the other technologies is particularly evident, not only in supporting clinical practice for acquiring the best evidence but also, for the regulatory purposes that are essential for medical applications. As already recognized for AM in a recent guideline [16], the micro-CT could represent a useful tool for the quality control of products and workflow. This last aspect has relevance for companies, but particularly for clinicians that often become themselves manufacturers in routine use of manufacturing techniques for custom applications in lab environments. The variability of the processes often requires keeping more parameters under control. In this framework, as suggested in the paragraph 3.1 for the more general topic, the elaboration of specific standards could represent the challenge and it could include all the steps from the segmentation, elaboration of 3D models, and adaptation for the numerical analysis to the checking of the final manufactured medical device, pre-surgery models or prototypes, and their traceability.

\section{Conclusions}

Micro-CT is an established technique that has demonstrated various advantages for many applications. In the last ten years, the improvement in image analysis allowed to highlight some opportunities offered by microtomographic technology, which until a decade ago, were considered only as potential benefits.

This overview aimed to collect and discuss the main topics investigated in studies carried out using laboratory micro-CT in dentistry and MFS, published in the last ten years and its potential in developing new studies, answering the main proposed research questions.

The discussed studies were rigorously collected by searching the main literature databases. After a full-text review, 105 articles were investigated from an initial total amount of 160 records obtained from the databases search. The graphic of Figure 3 allows visualizing the distribution in percentage of the total number of articles in relation to the topics and types of studies discussed in this work.

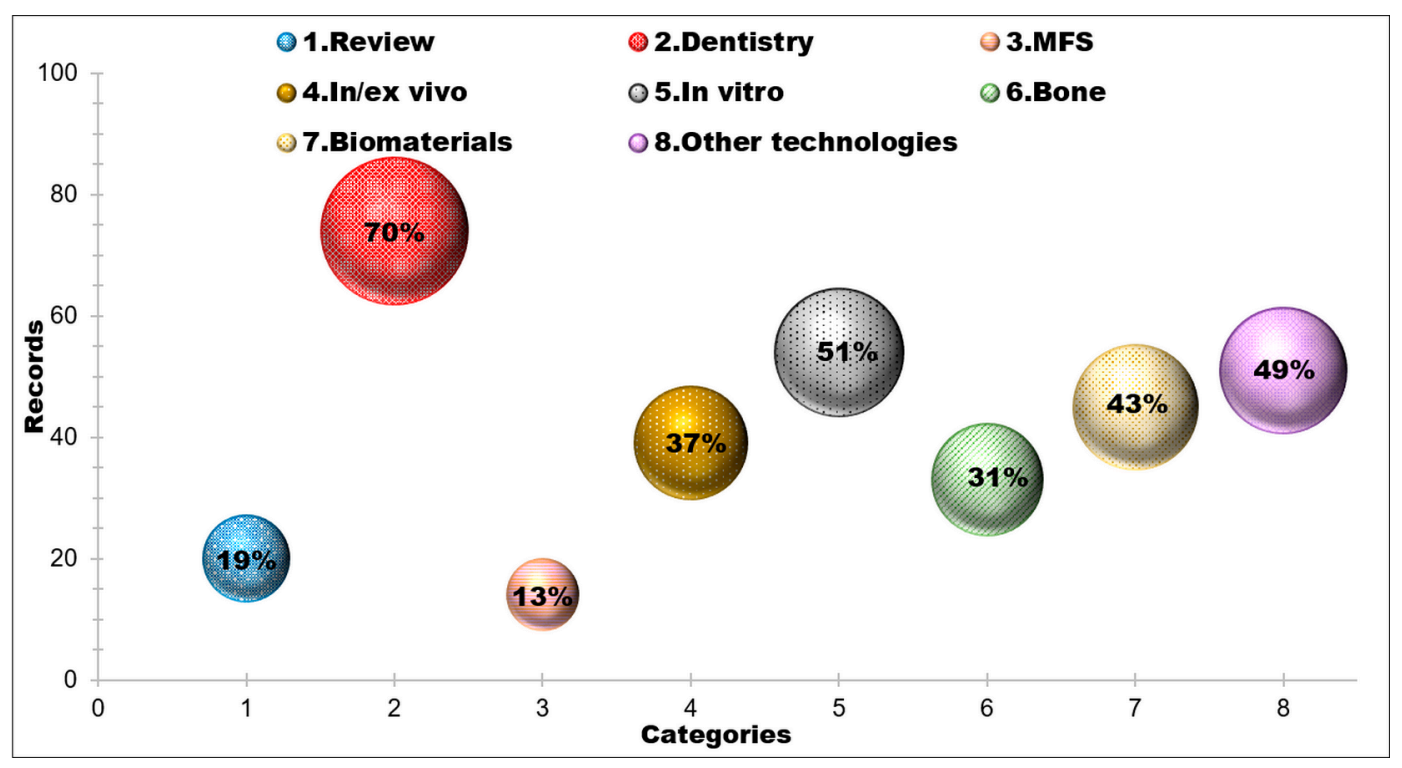

Figure 3. Distribution of the studies discussed in the text according to the topics indicated as the categories (1-8) on the horizontal axis; the number of records discussed in the text is indicated as an absolute value on the vertical axis and as a percentage value of the total studies considered in the graphical representation.

Starting from the literature evidence acquired by the reviews recorded (19\% of total records), the greater amount of studies, about $70 \%$, are focused on dentistry applications. MFS studies are limited, about $13 \%$ and some are associated with the analysis of treatments also applicable in dentistry 
(about 3\%). Micro-CT enables the scanning of objects with small dimensions and this aspect may have limited the adoption of the methodology, which is not suitable for some maxillofacial anatomical districts with respect to other tomography systems. From the point of view of the study typology, the percentages are similar for in vitro and in/ex vivo studies. It should be noted that some studies, about $12 \%$, use both approaches for defining a complete assessment.

The main detected records confirmed that an established range of micro-CT applications are related to studies performed to investigate new biomaterials and their effects on osseointegration, bone structure, bone grafts, and tissue response in dentistry. Furthermore, mineral tissues analyses, as well as evidence of specific treatments in orthodontia, represent the micro-CT core business. Most of the applications are effectuated in research settings and for scientific purposes.

Some limitations observed and that limited the spreading in clinical settings, were related to the operating costs and data processing time. Safety, cost-effectiveness, and efficiency still relieved to be some of the required challenges. Despite that, health care systems and private clinicians could benefit from it for various applications, traditional and emerging, as the assessment of patient-matched devices realized in point of care and based on 3D reconstructed models, eventually also for regulatory purposes.

This overview dedicated a section to the challenges of microtomographic evaluations combined with other technologies and techniques, highlighting the growing possibilities and the potential extension of the field of applications. Almost $49 \%$ of the discussed studies were carried out considering a multimethod approach using micro-CT with other techniques (Figure 3). Traditional methodologies as microscopy, histology, and mechanical characterization are confirmed conventionally associated with micro-CT. Numerical-based methods are the main emerging ones with a high potential growing and impact. The integrated approach is interesting and promising for the future developments.

The adoption of micro-CT in the daily clinical routine continues to represent the true goal. The definition of procedures or guidelines could allow a better comparison of the results for its use also integrated with other technologies and in relation to specific treatments. This last aspect associated with the developments of specific standards, and new quality control requirements for medical devices, could change the actual role of microtomographic analysis for a new prominent decade.

Author Contributions: Conceptualization and methodology, I.C. and R.P.; data curation, formal analysis, I.C.; investigation, I.C., R.P. and R.B.; visualization, I.C.; writing-original draft preparation, I.C.; writing-review and editing, I.C., R.P. and R.B. All authors have read and agreed to the published version of the manuscript.

Funding: This research received no external funding.

Conflicts of Interest: There are no potential conflicts of interest or, any financial, or, personal relationships with other people or organizations that could inappropriately bias conduct and findings of the study.

\section{References}

1. Rüegsegger, P.; Koller, B.; Müller, R. A microtomographic system for the nondestructive evaluation of bone architecture. Calcif. Tissue Int. 1996, 58, 24-29. [CrossRef] [PubMed]

2. Lin, A.S.P.; Stock, S.R.; Guldberg, R.E. Microcomputed tomography. In Springer Handbook of Microscopy; Hawkes, P.W., Spence, J.C.H., Eds.; Springer International Publishing: Cham, Germany, 2019; p. 2, ISBN 978-3-030-00069-1.

3. Liao, C.-W.; Fuh, L.-J.; Shen, Y.-W.; Huang, H.-L.; Kuo, C.-W.; Tsai, M.-T.; Hsu, J.-T. Self-assembled micro-computed tomography for dental education. PLoS ONE 2018, 13, e0209698. [CrossRef] [PubMed]

4. Deyhle, H.; Schmidli, F.; Krastl, G.; Müller, B. Evaluating tooth restorations: Micro-computed tomography in practical training for students in dentistry. Int. Soc. Optical Eng. 2010, 7804, 780417. [CrossRef]

5. Daly, S.M. Biophotonics for Blood Analysis; Elsevier: Amsterdam, The Netherlands, 2015; ISBN 9780857096746.

6. Campioni, I.; Cacciotti, I.; Gupta, N. Additive manufacturing of reconstruction devices for maxillofacial surgery: Design and accuracy assessment of a mandibular plate prototype. Ann. Ist. Super. Sanità 2020, 56, 10-18. [CrossRef] [PubMed] 
7. Mangione, F.; Meleo, D.; Talocco, M.; Pecci, R.; Pacifici, L.; Bedini, R. Comparative evaluation of the accuracy of linear measurements between cone beam computed tomography and 3D microtomography. Ann. Ist. Super. Sanità 2013, 49, 261-265. [CrossRef]

8. Sinibaldi, R.; Pecci, R.; Somma, F.; Penna, S.D.; Bedini, R. A new software for dimensional measurements in 3D endodontic root canal instrumentation. Ann. Ist. Super. Sanità 2012, 48, 42-48. [CrossRef]

9. Vögtlin, C.; Schulz, G.; Jäger, K.; Müller, B. Comparing the accuracy of master models based on digital intra-oral scanners with conventional plaster casts. Phys. Med. 2016, 1, 20-26. [CrossRef]

10. Cengiz, I.F.; Oliveira, J.M.; Reis, R.L. Micro-computed tomography characterization of tissue engineering scaffolds: Effects of pixel size and rotation step. J. Mater. Sci. Mater. Med. 2017, 28. [CrossRef]

11. Boerckel, J.D.; Mason, D.E.; McDermott, A.M.; Alsberg, E. Microcomputed tomography: Approaches and applications in bioengineering. Stem Cell Res. Ther. 2014, 5, 1-12. [CrossRef]

12. Sandholzer, M.A.; Walmsley, A.D.; Lumley, P.J.; Landini, G. Radiologic evaluation of heat-induced shrinkage and shape preservation of human teeth using micro-CT. J. Forensic Radiol. Imaging 2013, 1, 107-111. [CrossRef]

13. Rutty, G.N.; Brough, A.; Biggs, M.J.P.; Robinson, C.; Lawes, S.D.A.; Hainsworth, S.V. The role of micro-computed tomography in forensic investigations. Forensic Sci. Int. 2013, 225, 60-66. [CrossRef] [PubMed]

14. Bibb, R.; Thompson, D.; Winder, J. Computed tomography characterisation of additive manufacturing materials. Med. Eng. Phys. 2011, 33, 590-596. [CrossRef] [PubMed]

15. Pecci, R.; Baiguera, S.; Ioppolo, P.; Bedini, R.; Del Gaudio, C. 3D printed scaffolds with random microarchitecture for bone tissue engineering applications: Manufacturing and characterization. J. Mech. Behav. Biomed. Mater. 2020, 103, 103583. [CrossRef] [PubMed]

16. Center for Devices and Radiological Health. Technical Considerations for Additive Manufactured Medical Devices-Guidance for Industry and Food and Drug Administration Staff; Center for Devices and Radiological Health: Silver Spring, MD, USA, 2017; ISBN ISBN 3014271934.

17. Deyhle, H.; Dziadowiec, I.; Kind, L.; Thalmann, P.; Schulz, G.; Müller, B. Mineralization of early stage carious lesions in vitro-A quantitative approach. Dent. J. 2015, 3, 111-122. [CrossRef]

18. Davis, G.R.; Mills, D.; Anderson, P. Real-time observations of tooth demineralization in 3 dimensions using X-ray microtomography. J. Dent. 2018, 69, 88-92. [CrossRef] [PubMed]

19. Davis, G.; Mills, D. High-contrast x-ray microtomography in dental research. In Proceedings of the Developments in X-Ray Tomography XI, San Diego, CA, USA, 26 September 2017; Volume 10391, pp. 187-194.

20. Leeson, D. The digital factory in both the modern dental lab and clinic. Dent. Mater. 2019, 1, 43-52. [CrossRef]

21. Chalas, R.; Szlazak, K.; Wojcik-Checinska, I.; Jaroszewicz, J.; Molak, R.; Czechowicz, K.; Paris, S.; Swieszkowski, W.; Kurzydlowski, K.J. Observations of mineralised tissues of teeth in X-ray micro-computed tomography. Folia Morphol. 2017, 76, 143-148. [CrossRef]

22. Davis, G.R.; Evershed, A.N.Z.; Mills, D. Quantitative high contrast X-ray microtomography for dental research. J. Dent. 2013, 41, 475-482. [CrossRef]

23. Moinzadeh, A.T.; Zerbst, W.; Boutsioukis, C.; Shemesh, H.; Zaslansky, P. Porosity distribution in root canals filled with gutta percha and calcium silicate cement. Dent. Mater. 2015, 31, 1100-1108. [CrossRef]

24. Grande, N.M.; Plotino, G.; Gambarini, G.; Testarelli, L.; D’Ambrosio, F.; Pecci, R.; Bedini, R. Present and future in the use of micro-CT scanner 3D analysis for the study of dental and root canal morphology. Ann. Ist. Super. Sanità 2012, 48, 26-34. [CrossRef]

25. Meleo, D.; Bedini, R.; Pecci, R.; Mangione, F.; Pacifici, L. Microtomographic and morphometric characterization of a bioceramic bone substitute in dental implantology. Ann. Ist. Super. Sanità 2012, 48, 59-64. [CrossRef]

26. Barboni, B.; Mangano, C.; Valbonetti, L.; Marruchella, G.; Berardinelli, P.; Martelli, A.; Muttini, A.; Mauro, A.; Bedini, R.; Turriani, M.; et al. Synthetic bone substitute engineered with amniotic epithelial cells enhances bone regeneration after maxillary sinus augmentation. PLoS ONE 2013, 8, e63256. [CrossRef]

27. Bassi, M.A.; Bedini, R.; Pecci, R.; Ioppolo, P.; Lauritano, D.; Carinci, F. Mechanical properties of resin glass fiber-reinforced abutment in comparison to titanium abutment. J. Indian Soc. Periodontol. 2015, 19, $273-278$.

28. Bedini, R.; Pecci, R.; Marinozzi, F.; Bini, F.; Rizzo, G.; Campioni, I. Valutazione Morfometrica e Strutturale della Architettura del Tessuto Osseo Trabecolare del Collo del Femore: Analisi Microtomografica; Rapp. ISTISAN; Istituto Superiore di Sanità: Rome, Italy, 2018; pp. 1-36. 
29. Campioni, I.; Cacciotti, I.; Gupta, N. Additive manufacturing in ambito medicale: Valutazione di prototipi di dispositivi di fissaggio per chirurgia maxillo-facciale.In: Bedini R, Pecci R, Meleo D, Meli P, Scarano A. $6^{\circ}$ Convegno Nazionale FORM. Forum On Regenerative Methods. Istisan Congr. 2019, 19/C2, 12.

30. Campioni, I.; Pecci, R.; Pepe, E.; Bedini, R. Metodiche computazionali: Studio di fattibilità per l'analisi di strutture osso-biomateriale. In: Bedini R, Pecci R, Meli P, Meleo D. $2^{\circ}$ Convegno Nazionale FORM. Forum On Regenerative Methods. Le metodiche rigenerative nel Servizio Sanitario Nazionale. Istisan Congr. 2015, 15/C1, 7 .

31. Bedini, R.; Pecci, R.; Meleo, D.; Campioni, I. Bone substitutes scaffold in human bone: Comparative Evaluation by 3D Micro-CT Technique. Appl. Sci. 2020, 10, 3451. [CrossRef]

32. Barbetta, A.; Bedini, R.; Pecci, R.; Dentini, M. Role of X-ray microtomography in tissue engineering. Ann. Ist. Super. Sanità 2012, 48, 10-18. [CrossRef] [PubMed]

33. Brunke, O.; Brockdorf, K.; Drews, S.; Müller, B.; Donath, T.; Herzen, J.; Beckmann, F. Comparison between $\mathrm{x}$-ray tube-based and synchrotron radiation-based $\mu \mathrm{CT}$. In Proceedings of the Developments in X-Ray Tomography VI, San Diego, CA, USA, 16 September 2008; Volume 7078, p. 70780U.

34. Botta, L.M.; White, S.N.; Deyhle, H.; Dziadowiec, I.; Schulz, G.; Thalmann, P.; Müller, B. Comparing natural and artificial carious lesions in human crowns by means of conventional hard x-ray micro-tomography and two-dimensional x-ray scattering with synchrotron radiation. In Proceedings of the Developments in X-Ray Tomography X, San Diego, CA, USA, 4 October 2016; Volume 9967, pp. 53-63.

35. Dziadowiec, I.; Beckmann, F.; Schulz, G.; Deyhle, H.; Müller, B. Characterization of a human tooth with carious lesions using conventional and synchrotron radiation-based micro computed tomography. In Proceedings of the Developments in X-Ray Tomography IX, San Diego, CA, USA, 12 September 2014; Volume 9212, pp. 227-233.

36. Müller, B.; Deyhle, H.; Lang, S.; Schulz, G.; Bormann, T.; Fierz, F.C.; Hieber, S.E. Three-dimensional registration of tomography data for quantification in biomaterials science. Int. J. Mater. Res. 2012, 103, 242-249. [CrossRef]

37. Ogodescu, A.; Manescu, A.; Ogodescu, A.E.; Giuliani, A.; Todea, C. Micro-CT application for infiltration technology in paedodontics and orthodontics. In Proceedings of the Fifth International Conference on Lasers in Medicine: Biotechnologies Integrated in Daily Medicine, Imisoara, Romania, 19-21 September 2013; Todea, C., Podoleanu, A.G., Duma, V.-F., Eds.; SPIE: Bellingham, WA, USA, 2014; Volume 8925, pp. 51-56.

38. Brogle-Kim, Y.-C.; Deyhle, H.; Müller, B.; Schulz, G.; Bormann, T.; Beckmann, F.; Jäger, K. Evaluation of oral scanning in comparison to impression using three-dimensional registration. In Proceedings of the Developments in X-Ray Tomography VIII, San Diego, CA, USA, 13-15 August 2012; Stock, S.R., Ed.; SPIE: Bellingham, WA, USA, 2012; Volume 8506, pp. 437-445.

39. Luckow, M.; Deyhle, H.; Beckmann, F.; Dagassan-Berndt, D.; Müller, B. Tilting the jaw to improve the image quality or to reduce the dose in cone-beam computed tomography. Eur. J. Radiol. 2011, 80, e389-e393. [CrossRef]

40. Gugger, J.; Krastl, G.; Huser, M.; Deyhle, H.; Müller, B. The morphology of amputated human teeth and its relation to mechanical properties after restoration treatment. In Proceedings of the Developments in X-Ray Tomography VII, San Diego, CA, USA, 2-5 August 2010; Stock, S.R., Ed.; SPIE: Bellingham, WA, USA, 2010; Volume 7804, pp. 397-406.

41. Kofmehl, L.; Schulz, G.; Deyhle, H.; Filippi, A.; Hotz, G.; Berndt-Dagassan, D.; Kramis, S.; Beckmann, F.; Müller, B. Computed tomography to quantify tooth abrasion. In Proceedings of the Developments in X-Ray Tomography VII, San Diego, CA, USA, 2-5 August 2010; Stock, S.R., Ed.; SPIE: Bellingham, WA, USA, 2010; Volume 7804, pp. 375-384.

42. Dalstra, M.; Schulz, G.; Dagassan-Berndt, D.; Verna, C.; Müller-Gerbl, M.; Müller, B. Hard x-ray micro-tomography of a human head post-mortem as a gold standard to compare x-ray modalities. In Proceedings of the Developments in X-Ray Tomography X, San Diego, CA, USA, 29-31 August 2016; Stock, S.R., Müller, B., Wang, G., Eds.; SPIE: Bellingham, WA, USA, 2016; Volume 9967, pp. 37-42.

43. Latief, F.D.E.; Sari, D.S.; Fitri, L.A. Applications of Micro-CT scanning in medicine and dentistry: Microstructural analyses of a Wistar Rat mandible and a urinary tract stone. J. Phys. Conf. Ser. 2017, 884. [CrossRef]

44. Davis, G.R.; Mills, D. Brute force absorption contrast microtomography. In Proceedings of the Developments in X-Ray Tomography IX, San Diego, CA, USA, 12 September 2014; Volume 9212, p. 92120I. 
45. Kaisarly, D.; Gezawi, M. El Polymerization shrinkage assessment of dental resin composites: A literature review. Odontology 2016, 104, 257-270. [CrossRef]

46. Contrepois, M.; Soenen, A.; Bartala, M.; Laviole, O. Marginal adaptation of ceramic crowns: A systematic review. J. Prosthet. Dent. 2013, 110, 447-454. [CrossRef]

47. Ortiz, F.G.; Jimeno, E.B. Analysis of the porosity of endodontic sealers through micro-computed tomography: A systematic review. J. Conserv. Dent. 2018, 21, 238-242. [CrossRef]

48. Kalatzis-Sousa, N.G.; Spin-Neto, R.; Wenzel, A.; Tanomaru-Filho, M.; Faria, G. Use of micro-computed tomography for the assessment of periapical lesions in small rodents: A systematic review. Int. Endod. J. 2017, 50, 352-366. [CrossRef]

49. Ahmed, H.M.A.; Versiani, M.A.; De-Deus, G.; Dummer, P.M.H. A new system for classifying root and root canal morphology. Int. Endod. J. 2017, 50, 761-770. [CrossRef]

50. de Sousa-Neto, M.D.; Silva-Sousa, Y.C.; Mazzi-Chaves, J.F.; Carvalho, K.K.T.; Barbosa, A.F.S.; Versiani, M.A.; Jacobs, R.; Leoni, G.B. Root canal preparation using micro-computed tomography analysis: A literature review. Braz. Oral Res. 2018, 32 (Suppl. 1), e66. [CrossRef]

51. Velozo, C.; Albuquerque, D. Microcomputed Tomography studies of the effectiveness of XP-endo shaper in root canal preparation: A review of the literature. Sci. World J. 2019, 2019, 3570870. [CrossRef]

52. Junior, J.F.S.; das Rocas, I.N.; Marceliano-Alves, M.F.; Perez, A.R.; Ricucci, D. Unprepared root canal surface areas: Causes, clinical implications, and therapeutic strategies. Braz. Oral Res. 2018, 32 (Suppl. 1), e65. [CrossRef]

53. Rossi-Fedele, G.; Ahmed, H.M.A. Assessment of root canal filling removal effectiveness using micro-computed tomography: A systematic review. J. Endod. 2017, 43, 520-526. [CrossRef]

54. Zou, W.; Hunter, N.; Swain, M.V. Application of polychromatic microCT for mineral density determination. J. Dent. Res. 2011, 90, 18-30. [CrossRef]

55. Yeler, D.Y.; Koraltan, M.; Hocaoglu, T.P.; Arslan, C.; Erselcan, T.; Yeler, H. Bone quality and quantity measurement techniques in dentistry. Cumhur. Dent. J. 2016, 19, 73-86.

56. Ibrahim, N.; Parsa, A.; Hassan, B.; van der Stelt, P.; Wismeijer, D. Diagnostic imaging of trabecular bone microstructure for oral implants: A literature review. Dentomaxillofac. Radiol. 2013, 42, 20120075. [CrossRef]

57. Anderson, P.J.; Yong, R.; Surman, T.L.; Rajion, Z.A.; Ranjitkar, S. Application of three-dimensional computed tomography in craniofacial clinical practice and research. Aust. Dent. J. 2014, 59, 174-185. [CrossRef]

58. Irie, M.S.; Rabelo, G.D.; Spin-Neto, R.; Dechichi, P.; Borges, J.S.; Soares, P.B.F. Use of micro-computed tomography for bone evaluation in dentistry. Braz. Dent. J. 2018, 29, 227-238. [CrossRef]

59. Denry, I.; Kuhn, L.T. Design and characterization of calcium phosphate ceramic scaffolds for bone tissue engineering. Dent. Mater. 2016, 32, 43-53. [CrossRef]

60. Batool, F.; Strub, M.; Petit, C.; Bugueno, I.M.; Bornert, F.; Clauss, F.; Huck, O.; Kuchler-Bopp, S.; Benkirane-Jessel, N. Periodontal tissues, maxillary jaw bone, and tooth regeneration approaches: From animal models analyses to clinical applications. Nanomaterials 2018, 8, 337. [CrossRef]

61. Faot, F.; Chatterjee, M.; de Camargos, G.V.; Duyck, J.; Vandamme, K. Micro-CT analysis of the rodent jaw bone micro-architecture: A systematic review. Bone Rep. 2015, 2, 14-24. [CrossRef]

62. Annibali, S.; Bellavia, D.; Ottolenghi, L.; Cicconetti, A.; Cristalli, M.P.; Quaranta, R.; Pilloni, A. Micro-CT and PET analysis of bone regeneration induced by biodegradable scaffolds as carriers for dental pulp stem cells in a rat model of calvarial "critical size" defect: Preliminary data. J. Biomed. Mater. Res. B Appl. Biomater. 2014, 102, 815-825. [CrossRef]

63. Ide, Y.; Nakahara, T.; Nasu, M.; Matsunaga, S.; Iwanaga, T.; Tominaga, N.; Tamaki, Y. Postnatal mandibular cheek tooth development in the miniature pig based on two-dimensional and three-dimensional X-ray analyses. Anat. Rec. 2013, 296, 1247-1254. [CrossRef]

64. Baltacioglu, I.H.; Demirel, G.; Kolsuz, M.E.; Orhan, K. In-vitro analysis of maxillary first molars morphology using three dimensional Micro-CT imaging: Considerations for restorative dentistry. Eur. Oral Res. 2019, 52, 75-81. [CrossRef]

65. Kaizer, M.R.; Bano, S.; Borba, M.; Garg, V.; Dos Santos, M.B.F.; Zhang, Y. Wear Behavior of graded glass/zirconia crowns and their antagonists. J. Dent. Res. 2019, 98, 437-442. [CrossRef]

66. Lin, P.-Y.; Lyu, H.-C.; Hsu, C.-Y.S.; Chang, C.-S.; Kao, F.-J. Imaging carious dental tissues with multiphoton fluorescence lifetime imaging microscopy. Biomed. Opt. Express 2010, 2, 149-158. [CrossRef] 
67. Al-Rimawi, A.; EzEldeen, M.; Schneider, D.; Politis, C.; Jacobs, R. 3D Printed temporary veneer restoring autotransplanted teeth in children: Design and concept validation ex vivo. Int. J. Environ. Res. Public Health 2019, 16, 496. [CrossRef]

68. Kind, L.; Stevanovic, S.; Wuttig, S.; Wimberger, S.; Hofer, J.; Muller, B.; Pieles, U. Biomimetic remineralization of carious lesions by self-assembling peptide. J. Dent. Res. 2017, 96, 790-797. [CrossRef]

69. Maia, A.C.; Mangabeira, A.; Vieira, R.; de Neves, A.A.; Lopes, R.T.; Pires, T.M.; Viana, G.M.; Cabral, L.M.; Cavalcante, L.M.; Portela, M.B. Experimental composites containing quaternary ammonium methacrylates reduce demineralization at enamel-restoration margins after cariogenic challenge. Dent. Mater. 2019, 35, e175-e183. [CrossRef]

70. Ostapiuk, M.; Tarczydlo, B.; Surowska, B.; Orlowski, M.; Tymczyna, B.; Bachanek, T.; Rzepecka, A.; Mroz, A. Qualitative analysis of the margins of restorations made with different filling resins. Microsc. Res. Tech. 2018, 81, 823-831. [CrossRef]

71. Iwashita, T.; Mine, A.; Matsumoto, M.; Nakatani, H.; Higashi, M.; Kawaguchi-Uemura, A.; Kabetani, T.; Tajiri, Y.; Imai, D.; Hagino, R.; et al. Effects of three drying methods of post space dentin bonding used in a direct resin composite core build-up method. J. Prosthodont. Res. 2018, 62, 449-455. [CrossRef]

72. Matsumoto, M.; Mine, A.; Miura, J.; Minamino, T.; Iwashita, T.; Nakatani, H.; Nishida, T.; Takeshige, F.; Yatani, H. Bonding effectiveness and multi-interfacial characterization of two direct buildup resin core systems bonded to post-space dentin. Clin. Oral Investig. 2017, 21, 309-317. [CrossRef]

73. Belgin, C.A.; Serindere, G.; Orhan, K. Accuracy and reliability of enamel and dentin thickness measurements on micro-computed tomography and digital periapical radiographs ${ }^{\#}$. J. Forensic Radiol. Imaging 2019, 18, $32-36$.

74. Saito, K.; Takahashi, K.; Asahara, M.; Kiso, H.; Togo, Y.; Tsukamoto, H.; Huang, B.; Sugai, M.; Shimizu, A.; Motokawa, M.; et al. Effects of Usag-1 and Bmp7 deficiencies on murine tooth morphogenesis. BMC Dev. Biol. 2016, 16, 14. [CrossRef]

75. Minamino, T.; Mine, A.; Shintani, A.; Higashi, M.; Kawaguchi-Uemura, A.; Kabetani, T.; Hagino, R.; Imai, D.; Tajiri, Y.; Matsumoto, M.; et al. Advanced statistical analyses to reduce inconsistency of bond strength data. J. Dent. Res. 2017, 96, 1400-1405. [CrossRef]

76. Paredes, S.E.Y.; Segato, R.A.B.; Moreira, L.D.; Moreira, A.; Serrano, K.V.D.; Rodrigues, C.T.; Almeida, L.Y.; León, J.E. Dentoalveolar abscesses not associated with caries or trauma: A diagnostic hallmark of hypophosphatemic rickets initially misdiagnosed as hypochondroplasia. Head Neck Pathol. 2018, 12, 604-609. [CrossRef]

77. Khominsky, A.; Yong, R.; Ranjitkar, S.; Townsend, G.; Anderson, P.J. Extensive phenotyping of the orofacial and dental complex in Crouzon syndrome. Arch. Oral Biol. 2018, 86, 123-130. [CrossRef]

78. Yüksel, B.N.; Orhan, K.; Tulga Öz, F. Micro-CT evaluation of taurodontism in a deciduous molar and a permanent molar: Case report. Cumhur. Dent. J. 2019, 22, 486-490. [CrossRef]

79. Kaya, S.; Orhan, K.; Tulga Öz, F. Williams-beuren syndrome-A case report. Cumhur. Dent. J. 2019, 22, 481-485. [CrossRef]

80. Dannemann, M.; Kucher, M.; Kirsch, J.; Binkowski, A.; Modler, N.; Hannig, C.; Weber, M.-T. An approach for a mathematical description of human root canals by means of elementary parameters. J. Endod. 2017, 43, 536-543. [CrossRef]

81. Ziya, M.; Yüksel, B.N.; Şari, S. Root canal morphology of mandibular primary molars: A micro-ct study. Cumhur. Dent. J. 2019, 22, 382-389. [CrossRef]

82. Marceliano-Alves, M.F.; De Lima, C.O.; Augusto, C.M.; Barbosa, A.F.A.; Bruno, A.M.V.; Rosa, A.M.; Lopes, R.T. The internal root canal morphology of single-rooted mandibular canines revealed by micro-computed tomography. J. Conserv. Dent. 2018, 21, 588-591. [CrossRef]

83. Espir, C.; Nascimento, C.; Guerreiro-Tanomaru, J.; Bonetti-Filho, I.; Tanomaru-Filho, M. Radiographic and micro-computed tomography classification of root canal morphology and dentin thickness of mandibular incisors. J. Conserv. Dent. 2018, 21, 57-62.

84. Sachdeva, N.; Nikhil, V.; Jha, P. Effect of ultrasonic root-end cavity preparation on dentinal microcrack formation: A micro-computed tomography study. J. Conserv. Dent. 2019, 22, 362-366. [CrossRef]

85. Singh, V.; Nikhil, V.; Bansal, P. Induction of dentinal microcracks during postspace preparation: A comparative microcomputed tomography study. J. Conserv. Dent. 2018, 21, 646-650. [PubMed] 
86. Oishi, A.; Terashima, T.; Miyashin, M.; Takagi, Y. Repair processes of experimental root fractures in rat molars examined by histopathological techniques and 3D micro-CT imaging. Pediatr. Dent. J. 2013, 23, 8-15. [CrossRef]

87. Celikten, B.; Uzuntas, C.F.; Orhan, A.I.; Orhan, K.; Tufenkci, P.; Kursun, S.; Demiralp, K.O. Evaluation of root canal sealer filling quality using a single-cone technique in oval shaped canals: An in vitro Micro-CT study. Scanning 2016, 38, 133-140. [CrossRef] [PubMed]

88. Helvacioglu-Yigit, D.; Yilmaz, A.; Kiziltas-Sendur, G.; Aslan, O.S.; Abbott, P.V. Efficacy of reciprocating and rotary systems for removing root filling material: A micro-computed tomography study. Scanning 2014, 36, 576-581. [CrossRef] [PubMed]

89. Gao, S.; Tsoi, J.K.H.; Cheung, G.S.P.; Matinlinna, J. An in vitro evaluation on a novel root canal cleansing method by using nylon fibers. Fibers 2015, 3, 197-205. [CrossRef]

90. Alovisi, M.; Pasqualini, D.; Musso, E.; Bobbio, E.; Giuliano, C.; Mancino, D.; Scotti, N.; Berutti, E. Influence of contracted endodontic access on root canal geometry: An in vitro study. J. Endod. 2018, 44, 614-620. [CrossRef]

91. Krastl, G.; Gugger, J.; Deyhle, H.; Zitzmann, N.U.; Weiger, R.; Müller, B. Impact of adhesive surface and volume of luting resin on fracture resistance of root filled teeth. Int. Endod. J. 2011, 44, 432-439. [CrossRef]

92. Alshehri, M.; Alamri, H.M.; Alshwaimi, E.; Kujan, O. Micro-computed tomographic assessment of quality of obturation in the apical third with continuous wave vertical compaction and single match taper sized cone obturation techniques. Scanning 2016, 38, 352-356. [CrossRef]

93. Goymen, M.; Gulec, A. Effect of photobiomodulation therapies on the root resorption associated with orthodontic forces: A pilot study using micro computed tomography. Clin. Oral Investig. 2019, 24, 1431-1438. [CrossRef]

94. Minozzi, S.; Panetta, D.; De Sanctis, M.; Giuffra, V. A dental prosthesis from the early modern age in Tuscany (Italy). Clin. Implant Dent. Relat. Res. 2017, 19, 365-371. [CrossRef]

95. Nicklisch, N.; Maier, F.; Schulz, G.; Rossbach, A.; Pichler, S.L.; Zeilhofer, H.F.; Gutwald, R.; Dresely, V.; Meller, H.; Baumhoer, D.; et al. An osseous lesion in the maxillary sinus-Tumour or tumour-like? Int. J. Osteoarchaeol. 2019, 29, 183-190. [CrossRef]

96. Ozaki, M.; Takayama, T.; Yamamoto, T.; Ozawa, Y.; Nagao, M.; Tanabe, N.; Nakajima, A.; Suzuki, N.; Maeno, M.; Yamano, S.; et al. A collagen membrane containing osteogenic protein-1 facilitates bone regeneration in a rat mandibular bone defect. Arch. Oral Biol. 2017, 84, 19-28. [CrossRef] [PubMed]

97. Monteiro, N.; Smith, E.E.; Angstadt, S.; Zhang, W.; Khademhosseini, A.; Yelick, P.C. Dental cell sheet biomimetic tooth bud model. Biomaterials 2016, 106, 167-179. [CrossRef] [PubMed]

98. Charwat-Pessler, J.; Musso, M.; Petutschnigg, A.; Entacher, K.; Plank, B.; Wernersson, E.; Tangl, S.; Schuller-Gotzburg, P. A bone sample containing a bone graft substitute analyzed by correlating density information obtained by X-ray micro tomography with compositional information obtained by raman microscopy. Materials 2015, 8, 3831-3853. [CrossRef] [PubMed]

99. Boda, S.K.; Almoshari, Y.; Wang, H.; Wang, X.; Reinhardt, R.A.; Duan, B.; Wang, D.; Xie, J. Mineralized nanofiber segments coupled with calcium-binding BMP-2 peptides for alveolar bone regeneration. Acta. Biomater. 2019, 85, 282-293. [CrossRef]

100. Zhang, Y.; Yang, S.; Zhou, W.; Fu, H.; Qian, L.; Miron, R.J. Addition of a synthetically fabricated osteoinductive biphasic calcium phosphate bone graft to BMP2 improves new bone formation. Clin. Implant Dent. Relat. Res. 2016, 18, 1238-1247. [CrossRef]

101. Zhang, W.; Vazquez, B.; Oreadi, D.; Yelick, P.C. Decellularized tooth bud scaffolds for tooth regeneration. J. Dent. Res. 2017, 96, 516-523. [CrossRef]

102. Yeo, A.; Cheok, C.; Teoh, S.H.; Zhang, Z.Y.; Buser, D.; Bosshardt, D.D. Lateral ridge augmentation using a PCL-TCP scaffold in a clinically relevant but challenging micropig model. Clin. Oral Implants Res. 2012, 23, 1322-1332. [CrossRef]

103. Sha, J.; Kanno, T.; Miyamoto, K.; Bai, Y.; Hideshima, K.; Matsuzaki, Y. Application of a bioactive/bioresorbable three-dimensional porous uncalcined and unsintered Hydroxyapatite/Poly-D/L-lactide composite with human mesenchymal stem cells for bone regeneration in maxillofacial surgery: A pilot animal study. Materials 2019, 12, 705. [CrossRef] 
104. Bai, Y.; Sha, J.; Kanno, T.; Miyamoto, K.; Hideshima, K.; Matsuzaki, Y. Comparison of the bone regenerative capacity of three-dimensional uncalcined and unsintered Hydroxyapatite/Poly-d/l-lactide and beta-tricalcium phosphate used as bone graft substitutes. J. Invest. Surg. 2019, 1-14. [CrossRef] [PubMed]

105. Kumar, P.T.S.; Hashimi, S.; Saifzadeh, S.; Ivanovski, S.; Vaquette, C. Additively manufactured biphasic construct loaded with BMP-2 for vertical bone regeneration: A pilot study in rabbit. Mater. Sci. Eng. C Mater. Biol. Appl. 2018, 92, 554-564. [CrossRef] [PubMed]

106. Hatakeyama, W.; Taira, M.; Takafuji, K.; Kihara, H.; Kondo, H. Bone-regeneration trial of rat critical-size calvarial defects using nano-apatite/collagen composites. Nano Biomed. 2013, 5, 98-103.

107. Takayama, T.; Dai, J.; Tachi, K.; Shohara, R.; Kasai, H.; Imamura, K.; Yamano, S. The potential of stromal cell-derived factor-1 delivery using a collagen membrane for bone regeneration. J. Biomater. Appl. 2017, 31, 1049-1061. [CrossRef]

108. Thai, T.H.; Nuntanaranont, T.; Kamolmatyakul, S.; Meesane, J. In vivo evaluation of modified silk fibroin scaffolds with a mimicked microenvironment of fibronectin/decellularized pulp tissue for maxillofacial surgery. Biomed. Mater. 2017, 13, 15009. [CrossRef]

109. Moshaverinia, A.; Chen, C.; Akiyama, K.; Xu, X.; Chee, W.W.L.; Schricker, S.R.; Shi, S. Encapsulated dental-derived mesenchymal stem cells in an injectable and biodegradable scaffold for applications in bone tissue engineering. J. Biomed. Mater. Res. A 2013, 101, 3285-3294. [CrossRef] [PubMed]

110. Tatullo, M.; Spagnuolo, G.; Codispoti, B.; Zamparini, F.; Zhang, A.; Esposti, M.D.; Aparicio, C.; Rengo, C.; Nuzzolese, M.; Manzoli, L.; et al. PLA-based mineral-doped scaffolds seeded with human periapical Cyst-Derived MSCs: A promising tool for regenerative healing in dentistry. Materials 2019, 12, 597. [CrossRef] [PubMed]

111. Turco, G.; Porrelli, D.; Marsich, E.; Vecchies, F.; Lombardi, T.; Stacchi, C.; Lenarda, R. Di Three-dimensional bone substitutes for oral and maxillofacial surgery: Biological and structural characterization. J. Funct. Biomater. 2018, 9, 62. [CrossRef]

112. Zacchetti, G.; Dayer, R.; Rizzoli, R.; Ammann, P. Systemic treatment with strontium ranelate accelerates the filling of a bone defect and improves the material level properties of the healing bone. Biomed Res. Int. 2014, 2014. [CrossRef]

113. Schneider, D.A.; Smith, S.M.; Campbell, C.; Hayami, T.; Kapila, S.; Hatch, N.E. Locally limited inhibition of bone resorption and orthodontic relapse by recombinant osteoprotegerin protein. Orthod. Craniofac. Res. 2015, 18 (Suppl. 1), 187-195. [CrossRef]

114. Alikhani, M.; Lopez, J.A.; Alabdullah, H.; Vongthongleur, T.; Sangsuwon, C.; Alikhani, M.; Alansari, S.; Oliveira, S.M.; Nervina, J.M.; Teixeira, C.C. High-frequency acceleration: Therapeutic tool to preserve bone following tooth extractions. J. Dent. Res. 2016, 95, 311-318. [CrossRef] [PubMed]

115. da Fabris, A.L.S.; Mulinari-Santos, G.; Hassumi, J.S.; Freire, A.R.; Faverani, L.P.; Gruber, R.; Okamoto, R. Morphometric and histologic characterization of alveolar bone from hypertensive patients. Clin. Implant Dent. Relat. Res. 2017, 19, 1106-1113. [CrossRef] [PubMed]

116. Nepal, M.; Li, L.; Bae, T.S.; Kim, B.I.; Soh, Y. Evaluation of osseointegration around tibial implants in rats by ibandronate-treated nanotubular Ti-32Nb-5Zr alloy. Biomol. Ther. 2014, 22, 563-569. [CrossRef] [PubMed]

117. Qi, M.; Hu, J.; Li, J.; Li, J.; Dong, W.; Feng, X.; Yu, J. Effect of zoledronate acid treatment on osseointegration and fixation of implants in autologous iliac bone grafts in ovariectomized rabbits. Bone 2012, 50, 119-127. [CrossRef] [PubMed]

118. Wen, J.; Lu, T.; Wang, X.; Xu, L.; Wu, Q.; Pan, H.; Wang, D.; Liu, X.; Jiang, X. In vitro and in vivo evaluation of silicate-coated polyetheretherketone fabricated by electron beam evaporation. ACS Appl. Mater. Interfaces 2016, 8, 13197-13206. [CrossRef]

119. de Wild, M.; Schumacher, R.; Mayer, K.; Schkommodau, E.; Thoma, D.; Bredell, M.; Gujer, A.K.; Gratz, K.W.; Weber, F.E. Bone regeneration by the osteoconductivity of porous titanium implants manufactured by selective laser melting: A histological and micro computed tomography study in the rabbit. Tissue Eng. Part A 2013, 19, 2645-2654. [CrossRef]

120. Grau, M.; Seiler, C.; Roland, L.; Matena, J.; Windhovel, C.; Teske, M.; Escobar, H.M.; Lupke, M.; Seifert, H.; Gellrich, N.-C.; et al. Osteointegration of porous poly-epsilon-caprolactone-coated and previtalised magnesium implants in critically sized calvarial bone defects in the mouse model. Materials 2017, 11, 6. [CrossRef] 
121. Kubasiewicz-Ross, P.; Hadzik, J.; Dominiak, M. Osseointegration of zirconia implants with 3 varying surface textures and a titanium implant: A histological and micro-CT study. Adv. Clin. Exp. Med. 2018, 27, 1173-1179. [CrossRef]

122. Eger, M.; Sterer, N.; Liron, T.; Kohavi, D.; Gabet, Y. Scaling of titanium implants entrains inflammation-induced osteolysis. Sci. Rep. 2017, 7, 39612. [CrossRef]

123. Zeitouni, J.; Clough, B.; Zeitouni, S.; Saleem, M.; Al Aisami, K.; Gregory, C. The effects of the Er: YAG laser on trabecular bone micro-architecture: Comparison with conventional dental drilling by micro-computed tomographic and histological techniques. F1000Research 2017, 6, 1133. [CrossRef]

124. Umanjec-Korac, S.; Parsa, A.; Nikoozad, A.D.; Wismeijer, D.; Hassan, B. Accuracy of cone beam computed tomography in following simulated autogenous graft resorption in maxillary sinus augmentation procedure: An ex vivo study. Dentomaxillofac. Radiol. 2016, 45, 20160092. [CrossRef]

125. Monje, A.; Wu, Y.; Huang, W.; Zhou, W.; Galindo-Moreno, P.; Montanero-Fernandez, J.; Sheridan, R.; Wang, H.-L.; Wang, F. Influence of posterior mandibular dimensions on alveolar bone microarchitecture. Int. J. Oral Maxillofac. Implants 2017, 32, 423-430. [CrossRef] [PubMed]

126. Son, K.; Lee, S.; Kang, S.H.; Park, J.; Lee, K.-B.; Jeon, M.; Yun, B.-J. A comparison study of marginal and internal fit assessment methods for fixed dental prostheses. J. Clin. Med. 2019, 8, 785. [CrossRef] [PubMed]

127. Sen, S.; Erber, R.; Kunzmann, K.; Kirschner, S.; Weyer, V.; Schilling, L.; Brockmann, M.A.; Rues, S.; Orhan, G.; Lux, C.J.; et al. Assessing abrasion of orthodontic surface sealants using a modified ophthalmic optical coherence tomography device. Clin. Oral Investig. 2018, 22, 3143-3157. [CrossRef] [PubMed]

128. Song, J.C.; Suwanprateeb, J.; Sae-Lee, D.; Sosakul, T.; Pitiphat, W.; Prajaneh, S.; Kositbowornchai, S.; Putraphan, B. 2D and 3D pore structure characterization of bi-layered porous polyethylene barrier membrane using SEM and micro-CT. ScienceAsia 2019, 45, 159-171. [CrossRef]

129. Liu, S.; Broucek, J.; Virdi, A.S.; Sumner, D.R. Limitations of using micro-computed tomography to predict bone-implant contact and mechanical fixation. J. Microsc. 2012, 245, 34-42. [CrossRef] [PubMed]

130. Galibourg, A.; Dumoncel, J.; Telmon, N.; Calvet, A.; Michetti, J.; Maret, D. Assessment of automatic segmentation of teeth using a watershed-based method. Dentomaxillofac. Radiol. 2018, 47, 2017022. [CrossRef] [PubMed]

131. Özcan, C.; Josset, Y.; Muraille, C.; Lestriez, P.; Taiar, R. A three dimensional (3D) finite element model of restored molar teeth and combination of restorative material. Ser. Biomech. 2017, 31, 12-18.

132. Barbosa, J.M.; Tovar, N.; Tuesta, A.P.; Hirata, R.; Guimaraes, N.; Romanini, J.C.J.; Moghadam, M.; Coelho, P.G.; Jahangiri, L. Scan-layered reconstructions: A pilot study of a nondestructive dental histoanatomical analysis method and digital workflow to create restorations driven by natural dentin and enamel morphology. J. Esthet. Restor. Dent. 2017, 29, 256-263. [CrossRef]

133. Hegazy, M.A.A.; Eldib, M.E.; Mun, Y.J.; Cho, M.H.; Cho, M.H.; Lee, S.Y. A bench-top micro-CT capable of simulating head motions. Biomed. Eng. Lett. 2017, 7, 237-244. [CrossRef]

134. Lashgari, M.; Shahmoradi, M.; Rabbani, H.; Swain, M. Missing surface estimation based on modified tikhonov regularization: Application for Destructed dental tissue. IEEE Trans. Image Process. 2018, 27, 2433-2446. [CrossRef]

135. Da Silva, L.H.; Ribeiro, S.; Borges, A.L.S.; Cesar, P.F.; Tango, R.N. FEA and microstructure characterization of a one-piece Y-TZP abutment. Dent. Mater. 2014, 30, e283-e288. [CrossRef] [PubMed]

136. Magne, P. Virtual prototyping of adhesively restored, endodontically treated molars. J. Prosthet. Dent. 2010, 103, 343-351. [CrossRef]

137. Kinoshita, H.; Nagahata, M.; Takano, N.; Takemoto, S.; Matsunaga, S.; Abe, S.; Yoshinari, M.; Kawada, E. Development of a drilling simulator for dental implant surgery. J. Dent. Educ. 2016, 80, 83-90. [CrossRef] [PubMed]

138. Chang, C.H.; Lei, Y.N.; Ho, Y.H.; Sung, Y.H.; Lin, T.S. Predicting the holistic force-displacement relation of the periodontal ligament: In-vitro experiments and finite element analysis. Biomed. Eng. Online 2014, 13, 1-11. [CrossRef] [PubMed]

139. Benazzi, S.; Grosse, I.R.; Gruppioni, G.; Weber, G.W.; Kullmer, O. Comparison of occlusal loading conditions in a lower second premolar using three-dimensional finite element analysis. Clin. Oral Investig. 2014, 18, 369-375. [CrossRef] [PubMed] 
140. Ossareh, A.; Rosentritt, M.; Kishen, A. Biomechanical studies on the effect of iatrogenic dentin removal on vertical root fractures. J. Conserv. Dent. 2018, 21, 290-296. [PubMed]

141. Kato, C.N.; Barra, S.G.; Tavares, N.P.; Amaral, T.M.; Brasileiro, C.B.; Mesquita, R.A.; Abreu, L.G. Use of fractal analysis in dental images: A systematic review. Dentomaxillofac. Radiol. 2019, 20180457. [CrossRef]

(C) 2020 by the authors. Licensee MDPI, Basel, Switzerland. This article is an open access article distributed under the terms and conditions of the Creative Commons Attribution (CC BY) license (http://creativecommons.org/licenses/by/4.0/). 